\title{
23 Trees on farms and farmers in the forest
}

\section{Good practices and a need for policy}

\author{
Ingrid Öborn, Rhett D. Harrison \\ and Sileshi G. Weldesemayat
}

\section{Introduction}

Sustainable intensification of smallholder farming that includes linking production to markets has been a recent focus of research, innovation and development activities in sub-Saharan Africa (e.g., Öborn et al., 2017). Agroforestry - or the integration of trees with crops and/or livestock and diversification of farm production and income sources with tree derived products - is one strategy to sustainably intensify livelihoods' systems and make them more resilient to climate change and other shocks (e.g., Minang et al., 2015). Introducing woody perennials (shrubs and trees) on farmland has been shown to improve food and nutrition security and increase household income (Ajayi et al., 2009, 2011). In addition, planting trees enhances the delivery of products (timber, firewood, fruits, etc.) and increases ecosystem services benefits such as improved soil fertility, microclimate (shade or wind break) and water infiltration capacity (Kuyah et al., 2016). Although, the choice of tree species and agroforestry practices, i.e., how trees are integrated and managed on a farm, differs widely depending on: farmers' resources and needs, climate, soil type, institutional arrangements, knowledge and incentives, e.g., extension, farmers' groups, loan schemes (van Noordwijk, 2019). Trees on farms also mitigate climate change by locking up atmospheric carbon in biomass and soils and improve the environment for biodiversity. Unsurprisingly, therefore agroforestry is often viewed as a win-win option for improving livelihoods and delivering environmental benefits.

In sub-Saharan Africa, wood-fuel accounts for more than $80 \%$ of primary energy supply; the vast majority of the population relies on firewood and charcoal for energy, especially for cooking (Iiyama et al., 2014). In rural areas in Southern Africa, firewood is the main sources of energy making access to trees of vital importance, while most urban populations depend on charcoal. Moreover, much of the wood for energy comes from forests resulting in forest degradation. However, there is a huge potential for agroforestry and farm forestry to produce firewood for domestic use and sale and support sustainable charcoal production, which can generate cash income (Iiyama et al., 2014).

This chapter will explore the roles and potentials of trees on farms and farmers in forests for rural transformation in Southern Africa. We describe 
experiences from on farm integration of nitrogen fixing trees (fertilizer trees) and illustrate how that can affect productivity of maize, vegetables and dairy cattle as well as provide firewood and other ecosystem services and increase farmers' incomes. We demonstrate the importance of community forestry initiatives for smallholders and suggest incentives for communities to protect and sustainably use forest resources.

\section{Integration of fertilizer trees in crop and livestock systems in Southern Africa}

Fertilizer tree systems refer to agroforestry practices involving nitrogen-fixing leguminous perennials in crop production, pastures, rangelands and rehabilitation of degraded land (Sileshi et al., 2014). Most fertilizer tree systems have been designed to address problems with soil health and raise crop and livestock productivity in an integrated manner. The contribution of fertilizer trees to soil improvement mainly comes from nitrogen $(\mathrm{N})$ inputs via biological nitrogen fixation (BNF) and the capture of nutrients by tree roots from soil depths beyond the reach of crop roots and their transfer to the soil surface through litter fall, tree pruning and their biological decomposition. There are many agroforestry practices that capitalize on BNF from fertilizer trees (Sileshi et al., 2014); those relevant to the Southern African context will be described here.

\section{Agroforestry practices for maize mixed farming systems}

A maize mixed farming system is a crop and livestock integrated system where the dominant crop is maize but which also includes pulses, vegetables, oilseeds and root crops. The livestock component includes cattle, small ruminants and poultry. This system covers a large portion of Southern Africa including Zambia, Malawi, Mozambique, Zimbabwe, Botswana, South Africa, Swaziland, Lesotho and Madagascar. In this system, fertilizer trees are integrated to improve soil fertility and provide animal fodder and other tree products including firewood, poles and timber. In this farming system, improved fallows, relay cropping and intercropping with fertilizer trees have been used to improve soil health and increase crop productivity.

Research conducted in the last two decades in Malawi, Mozambique, Zambia and Zimbabwe demonstrated that fertilizer trees can double or triple yields of maize contributing to food security (Ajayi et al., 2011; Akinnifesi et al., 2010; Sileshi et al., 2014) and reducing production risks (Sirrine et al., 2010). A metaanalysis of published studies found that maize yields can be doubled or tripled relative to unfertilized maize in $45-67 \%$ of cases with fertilizer trees (Sileshi et al., 2008, 2014). An additional benefit that is usually underreported in the literature is the stover yield, which is a critical input as a soil cover and livestock feed. Estimates show that $0.2-2.0 \mathrm{t} \mathrm{ha}^{-1} \mathrm{yr}^{-1}$ of stover can be produced using fertilizer tree systems (Sileshi et al., 2014). In addition, studies on research stations in Zambia have demonstrated that fertilizer trees can reduce weed problems 
(e.g., Striga) and insect pests of maize, especially termites (Pumariño et al., 2015; Sileshi et al., 2005, 2006).

There is substantial evidence showing that fertilizer trees are profitable in terms of returns to land and labour. For example, the net present values (NPV) and benefit cost ratios (BCR) show that fertilizer trees are either comparable or better than the application of inorganic fertilizer in maize cropping (Ajayi et al., 2009). Over a five-year cycle in eastern Zambia, the discounted net benefit of maize grown with Gliricidia (US\$327 ha-1), Sesbania (US\$309 ha $\mathrm{h}^{-1}$ ) and Tephrosia (US $\$ 233 \mathrm{ha}^{-1}$ ) compared favourably with maize grown with a recommended inorganic fertilizer (US $\$ 349 \mathrm{ha}^{-1}$ ). With respect to returns per investment, fertilizer trees performed even better (BCR: 2.8-3.1) than the recommended fertilizer purchased at market price (BCR: 1.8 ) or at $50 \%$ government subsidy of fertilizer (BCR: 2.6) (e.g., Ajayi et al., 2009). Similarly, in central Malawi, intercropping maize with pigeon pea consistently had positive returns across the farmers' resource groups indicating its suitability for a wide range of environments and for poorer farmers (Kamanga et al., 2010).

\section{Biomass transfer for vegetable production in wetlands}

Biomass transfer using green manure from fertilizer trees has shown promise in sustainable vegetable production in wetland and nutrition gardens. Biomass transfer is essentially moving green leaves and twigs from one location to another to be used as green manure. Although wetlands are considered extremely vulnerable to poor agricultural practices, rising population pressures have caused their agricultural use to become increasingly important. Wetlands - called dambo in Zambia and Malawi, vlei in Zimbabwe and South Africa, molapo in Botswana, Namibia and Lesotho and naka in Angola - are extremely important for dry season agriculture, grazing and water supply (Kuntashula et al., 2004). Traditionally, dry season production of vegetables has been widely practiced in wetlands, particularly in communal areas. With the recent emphasis on nutrition gardens, their utilization is increasing.

Nutrition gardens are often promoted by NGOs and church organizations, targeting the poor and the sick, especially HIV patients, with the aim of improving their standards of living with more emphasis on nutrition and income generation. Nutrition garden sites are often located close to water sources, which often tend to be wetlands. Biomass transfer has been demonstrated to be a sustainable means for maintaining soil-nutrient balances in vegetable production systems in the wetlands in Southern Africa (e.g., Kuntashula et al., 2004, 2006). The trees can be planted on cropland, degraded land or in silvopastoral systems and pruned or lopped. Depending on the nutrient requirement of the vegetable crop, $4-12 \mathrm{t} \mathrm{ha}^{-1}$ of leafy biomass (on dry matter basis) may be applied for increased productivity. This method has been demonstrated to be highly profitable in the production of cabbage, rape, onion, garlic and tomato in eastern Zambia (e.g., Kuntashula et al., 2004, 2006). 


\section{Fodder trees to improve dairy production}

Fertilizer trees have been integrated with livestock production systems, called silvopastoral systems, in Southern Africa with varying degrees of success. Silvopastoral systems may be divided into two broad categories: fodder banks (also called protein banks) and grazing systems. In the protein bank approach, the animals are stall-fed with fodder collected from fertilizer trees grown in blocks on farmland. In the more extensive grazing areas, fertilizer trees are increasingly being planted in association with improved grasses to increase the carrying capacity of pastures or enhance the productivity of grazing cattle. A review of work carried out in Tanzania, Malawi and Zimbabwe has provided substantial evidence of improvement in smallholders' dairy productivity using fodder banks (Chakeredza et al., 2007).

\section{Trees for providing other ecosystem services on farms}

Substantial amounts of firewood can be produced through planting trees in various niches (Kamanga et al., 1999; Sileshi et al., 2007; Figure 23.1). According

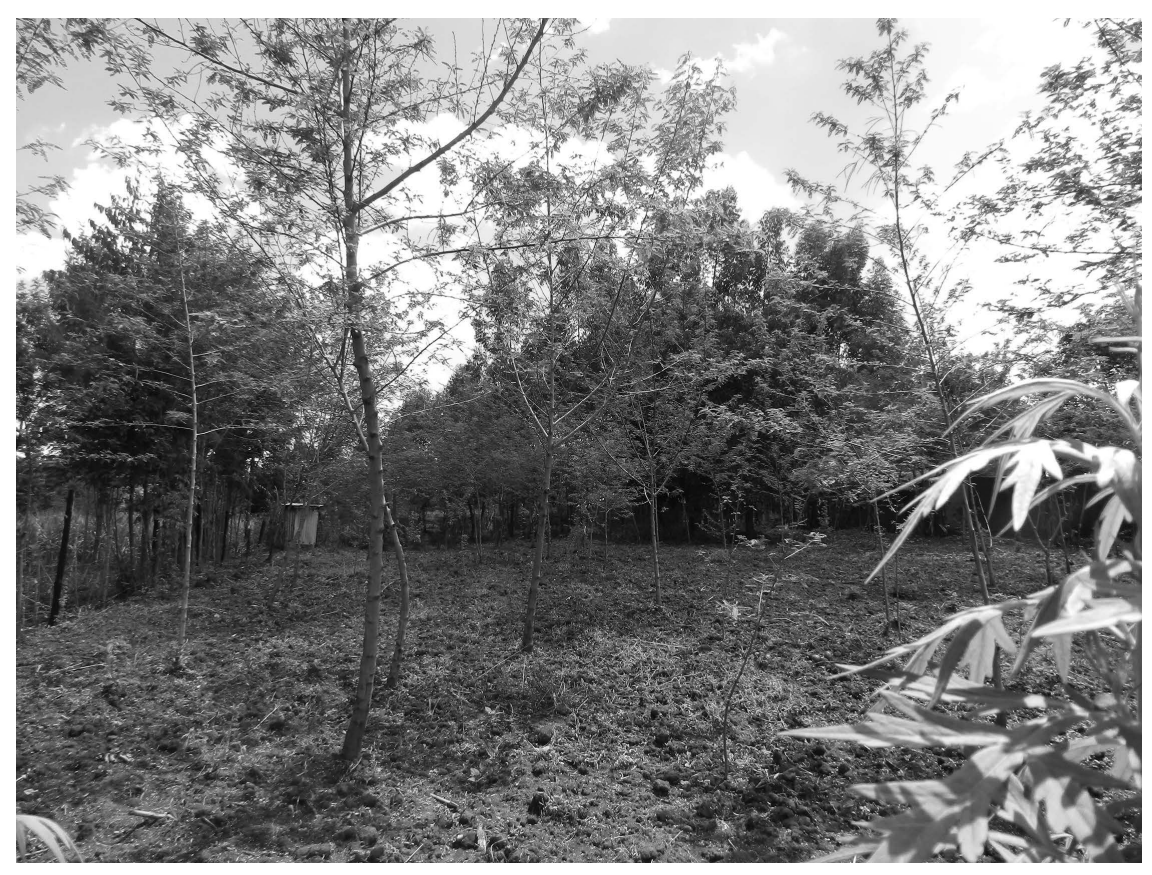

Figure 23.1 Sesbania planted as a relay crop in a maize field on a smallholder farm to improve soil fertility and provide firewood

Source: Photo Ingrid Öborn 
to Kamanga et al. (1999), 92-101\% of domestic fuelwood needs were met from a hectare of 2-3-year-old Sesbania fallows in Malawi. Fertilizer trees also provide other ecosystem services in Southern Africa (Kuyah et al., 2016; Sileshi et al., 2007, 2014). Planting or managing naturally regenerating fertilizer trees can also tighten $\mathrm{N}$ cycling in the cropping system, increase carbon sequestration, reduce the need for fertilizer $\mathrm{N}$ inputs and lower greenhouse gas emissions (Sileshi, 2016; Sileshi et al., 2014). For example, the wider use of these trees in mixed crop and livestock systems can reduce methane emissions and increase carbon sequestration (Kim et al., 2016; Sileshi et al., 2014). Inclusion of tannin rich fodder in animal feeds can reduce enteric $\mathrm{CH}_{4}$ production due to the anti-methogenic activity of tannins (Patra and Saxene, 2011). Net soil $\mathrm{CH}_{4}$ emissions were also reduced when agriculture was shifted to improved fallow (Kim et al., 2016).

Rural households in Southern Africa use trees extensively within their farming systems. The trees can be planted or remnant trees. Trees supply wood fuel for household energy needs and charcoal for sale to urban centres. Trees supply timber for construction, including for example poles for building drying sheds for tobacco. People extensively harvest forest fruits and also grow fruit trees on their own land. Lastly, trees provide ecosystem services to farmers, such as shade and shelter for crops, livestock and people and enhance soil conditions. For example, a recent survey among vulnerable farmers (median hh income $=$ US $\$ 200 ; 80 \%$ reported going hungry for one month or more) in Eastern Province, Zambia found that most households identified fuel and food as the main uses of trees, with approximately $20 \%$ also identifying medicines and "land benefits" (aka soil improvement) (Figure 23.2, left).

\section{Farmers in the forest}

\section{Community forestry}

Even where farmers practice more intensified farming, they use forests extensively. They depend on forests for a large part of their fuel needs and also harvest food from the forest (Figure 23.2, top graph). In the past, this dependence on forests for their livelihoods has often set them at odds with local and national authorities who control forest resources. In Zambia a recent change to the forest law (Government of Zambia, 2015, 2018) enabled the establishment of community forests. Under forest management agreements, local communities can gain access to tree resources, such as wood for timber and charcoal production and can collect forest products, like honey, mushrooms and fruit (Figure 23.2, bottom graph). That is, the law provides the right to harvest forest resources. Under the agreement, there are management responsibilities, which would normally include protection of the forest and limiting harvesting of tree resources to agreed-upon sustainable rates. Because of the relative novelty of the concept of community forests in Zambia, and a lack of capacity among district forest offices to negotiate community forest agreements, the uptake to date has been limited 

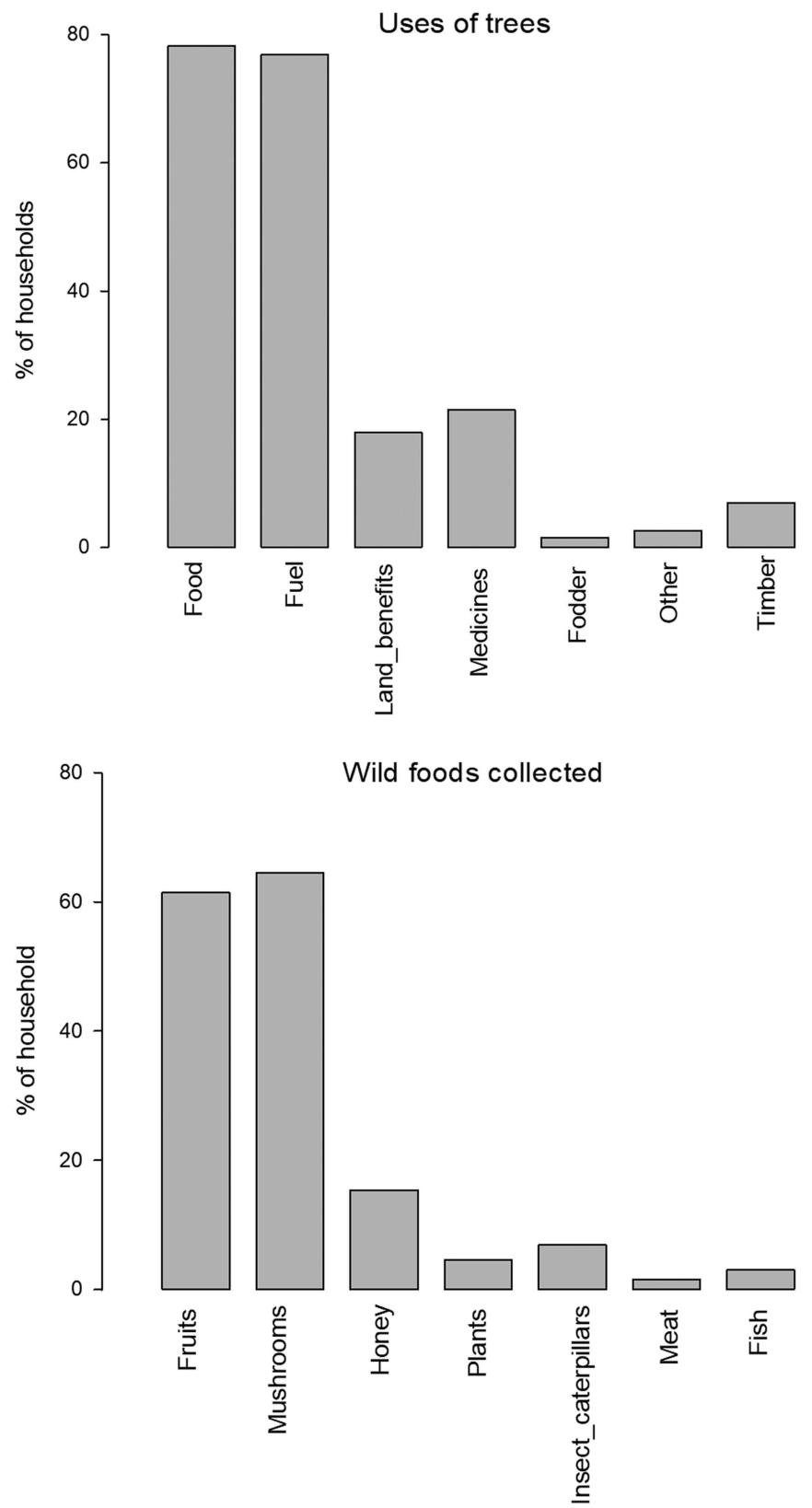

Figure 23.2 Farmers in Zambia are using trees and forest products as part of their livelihoods Top: a recent survey in the eastern province of Zambia showed that a majority of farmers are using trees for fuel and food, $20 \%$ also identified medicines and "land benefits" (aka soil improvement)

Bottom: farmers are collecting wild food, in particular fruits, mushrooms and honey, in the forest 
(33,190 ha as of July 2018). In addition, the government taxes the products, and this has been identified as a disincentive for rural communities to change from the current open access situation. Nonetheless, community forests could be a useful policy tool for delivering more sustainable forest management in a country where forests are widely used by rural communities, but the national government is unable to govern natural resource use. In particular, community forests (Gilmour, 2016) could offer an option for making the charcoal industry more sustainable.

Currently, a large proportion of the charcoal in Zambia is produced by migrant woodcutters who do not bear any of the externalities generated by their activities. Local communities are dis-incentivized to control access to their forests because their resource rights are not guaranteed. Hence, designation of community forests could incentivize communities to protect their forest resources and push the charcoal industry towards a more sustainable path.

\section{Concluding remarks and ways forward}

While the scientific foundation for promoting trees on farms has been solid, the challenge has been scaling-up to benefit the millions of smallholders seeking their livelihoods on marginal lands in Southern Africa (Stevenson and Vlek, 2018). The bottlenecks need to be identified and options for creating enabling environments and incentives generated.

There is possibility for farmers and local communities to engage in forestry in Southern Africa in a sustainable manner. The designation of community forests (Gilmour, 2016) is one option.

Over the past five decades, agroforestry science has gone from research on tree species and agroforestry practices on farms, through to studies of the roles of trees in multifunctional landscapes, to more recently paying attention to understanding the agroforestry policy domain and how to bridge the policy gap between agriculture and forestry policies (van Noordwijk, 2019).

To facilitate agroforestry development in Southern African countries and help bridge the gap between policy spheres, the Southern African Development Community (SADC) could develop Guidelines for Agroforestry Development, following the example from Southeast Asia (ASEAN, 2018). Similar developments could guide community forestry in the SADC countries. Adoption of national agroforestry, as for example in Zambia (ZARI and ICRAF, 2013), and community forestry strategies and guidelines can bridge the agriculture and forestry policy divide and enable and incentivize farmers and rural communities to engage in sustainable management of trees and tree products as means to transform their lives and livelihoods.

\section{References}

Ajayi, O. C., Akinnifesi, F. K., Sileshi, G. and Kanjipite, W. (2009) Labor input and financial profitability of conventional and agroforestry-based soil fertility management practices in Zambia. Agrekon 48: 276-292. 
Ajayi, O., Place, F., Akinnifesi, F. and Sileshi, G. (2011) Agricultural success from Africa: the case of fertilizer tree systems in southern Africa (Malawi, Tanzania, Mozambique, Zambia and Zimbabwe). International Journal of Agricultural Sustainability 9: 129-136.

Akinnifesi, F. K., Ajayi, O. C., Sileshi, G., Chirwa, P. W. and Chianu, J. (2010) Fertiliser trees for sustainable food security in the maize-based production systems of East and Southern Africa. A review. Agronomy for Sustainable Development 30: 615-619.

[ASEAN] Association of Southeast Asian Nations (2018) ASEAN Guidelines for Agroforestry Development. Authors: Catacutan, D. C., Finlayson, R. F., Gassner, A., Perdana, A., Lusiana, B., Leimona, B., Simelton, E., Öborn, I., Galudra, G., Roshetko, J. M., Vaast, P., Mulia, R., Lasco, R. L., Dewi, S., Borelli, S., Yasmi, Y. Jakarta, Indonesia: ASEAN Secretariat.

Chakeredza, S., Hove, L., Akinnifesi, F. A., Franzel, S., Ajayi, O. and Sileshi, G. (2007) Managing fodder trees as a solution to human-livestock food conflicts and their contribution to income generation for smallholder farmers in Southern Africa. Natural Resources Forum 31: $286-291$.

Gilmour, D. (2016) Forty years of community-based forestry. A review of its extent and effectiveness. FAO Forestry Paper 176. Rome, Italy; Food and Agriculture Organization of the United Nations.

Government of Zambia (2015) The Forests Act, 2015 (No. 4 of 2015): 81-139.

Government of Zambia (2018) The Forests Act, 2015 (Act No. 4 of 2015). The Forests (Community Forest Management) Regulations, 2018. STATUTORY INSTRUMENT NO. 11 of 2018, Supplement to the Republic of Zambia Government Gazette dated Friday, 23rd February, 2018: 77-98.

Iiyama M., Neufeldt, H., Dobie, P., Njenga, M., Ndegwa, G. and Jamnadass, R. (2014) The potential of agroforestry in the provision of sustainable woodfuel in sub-Saharan Africa. Current Opinion in Environmental Sustainability 6: 138-147.

Kamanga, B. C. G., Kanyama-Phiri, G.Y. and Minae, S. (1999). Intercropping perennial legumes for green manure additions to maize in southern Malawi. African Crop Science Journal, 7: 355-363.

Kamanga, B. C. G., Waddington, S. R., Robertson M. J. and Giller K. E. (2010) Risk analysis of maize-legume crop combinations with smallholder farmers varying in resource endowment in central Malawi. Experimental Agriculture 46: 1-21.

Kim D-G., Kirschbaum, M. U. F. and Beedy, T. L. (2016) Carbon sequestration and net emissions of $\mathrm{CH}_{4}$ and $\mathrm{N}_{2} \mathrm{O}$ under agroforestry: Synthesizing available data and suggestions for future studies. Agriculture, Ecosystems and Environment 226: 65-78.

Kuntashula, E., Mafongoya, P. L., Sileshi, G. and Lungu, S. (2004) Potential of biomass transfer technologies in sustaining vegetable production in the wetlands (dambos) of eastern Zambia. Experimental Agriculture 40: 37-51.

Kuntashula, E., Sileshi, G., Mafongoya, P. L. and Banda, J. (2006) Farmer participatory evaluation of the potential for organic vegetable production in the wetlands of Zambia. Outlook on Agriculture 35: 299-305.

Kuyah, S., Öborn, I.,Jonsson, M., Dahlin, A. S., Barrios, E., Muthuri, C., Malmer, M., Nyaga,J., Magaju, C., Namirembe, S., Nyberg, Y. and Sinclair, F. L. (2016) Trees in agricultural landscapes enhance provision of ecosystem services in Sub-Saharan Africa, International Journal of Biodiversity Science, Ecosystem Services \& Management 12: 4, 255-273.

Minang, P. A., van Noordwijk, M., Freeman, O. E., Mbow, C., de Leeuw, J. and Catacutan, D., eds. (2015) Climate-Smart Landscapes: Multifunctionality in Practice. Nairobi, Kenya: World Agroforestry Centre (ICRAF) (http://asb.cgiar.org/climate-smart-landscapes/ index.html). 


\section{Ingrid Öborn et al.}

van Noordwijk, M., ed. (2019) Sustainable Development Through Trees on Farms: Agroforestry in Its Fifth Decade. Bogor, Indonesia: World Agroforestry (ICRAF), pp 420 (www.worldagro forestry.org/trees-on-farms).

Öborn, I., Vanlauwe, B., Philips, M., Thomas, R., Brooijmans, W., Atta-Krah, K., eds. (2017) Sustainable Intensification in Smallholder Agriculture. An Integrated Systems Research Approach. London, UK: Earthscan Food and Agriculture, Routledge. 381 pp. https://cgspace.cgiar. org/handle/10568/89642.

Patra, A. K. and Saxene, J. (2011) Exploitation of dietary tannins to improve rumen metabolism and ruminant nutrition. Journal of the Science of Food and Agriculture 91: 24-37.

Pumariño, L., Sileshi, G, W., Gripenberg, S., Kaartinen, R., Barrios, E., Muchane, M. N., Midega, C., Jonsson, M. (2015) Effects of agroforestry on pest, disease and weed control: a meta-analysis. Basic and Applied Ecology 16: 573-582.

Sileshi, G. W. (2016) The magnitude and spatial extent of Faidherbia albida influence on soil properties and primary productivity in drylands. Journal of Arid Environments 132: 1-14.

Sileshi, G. W., Akinnifesi, F. K., Ajayi, O. C., Chakeredza, S., Kaonga, M., Matakala, P. (2007) Contribution of agroforestry to ecosystem services in the Miombo eco-region of eastern and southern African. African Journal of Environmental Science and Technology 1(4): 68-80.

Sileshi, G. W., Akinnifesi, F., Ajayi, O. C. and Place, F. (2008) Meta-analysis of maize yield response to woody and herbaceous legumes in sub-Saharan Africa. Plant and Soil 307 (1-2): 1-19.

Sileshi, G. W., Mafongoya, P. L., Akinnifesi, F. K., Phiri, E., Chirwa, P., Beedy, T., Makumba, W., Nyamadzawo, G., Njoloma, J., Wuta, M., Nyamugafata, P. and Jiri, O. (2014) Fertilizer trees. In: van Alfen, N. K. Encyclopedia of Agriculture and Food Systems, Vol. 1, San Diego: Elsevier, pp. 222-234.

Sileshi, G. W., Mafongoya, P. L., Kwesiga, F., Nkunika, P. (2005) Termite damage to maize grown in agroforestry systems, traditional fallows and monoculture on nitrogen-limited soils in eastern Zambia. Agricultural and Forest Entomology 7: 61-69.

Sileshi, G. W., Kuntashula, E. and Mafongoya, P. L. (2006) Effect of improved fallows on weed infestation in maize in eastern Zambia. Zambia Journal of Agricultural Science 8(2): 6-12.

Sirrine, D., Shennan, C., Snapp, S., Kanyama-Phiri, G., Kamanga, B. and Sirrine, J. R. (2010) Improving recommendations resulting from on-farm research: Agroforestry, risk, profitability and vulnerability in southern Malawi. International Journal of Agricultural Sustainability 8: 290-304.

Stevenson, J. R. and Vlek, P. (2018) Assessing the Adoption and Diffusion of Natural Resource Management Practices: Synthesis of a New Set of Empirical Studies. Rome: Independent Science and Partnership Council (ISPC).

ZARI and ICRAF (2013) National Agroforestry Strategy 2013-2020, November 2013, Lusaka, Zambia. 